\title{
Activation Patterns of the Nucleolar Organizer Region in Astyanax scabripinnis Populations (Pisces, Characidae)
}

\author{
Sonia Maria Hiromi Nagasawa Mizoguchi and Isabel Cristina Martins-Santos \\ Department of Biologia Celular e Genética, Universidade Estadual de Maringá, 87020-900-Maringá, Pr. Brasil
}

Accepted March 16, 1998

\begin{abstract}
Summary The analysis of the nucleolar organizer regions (NORs) in 4 Astyanax scabripinnis populations collected in the Yukatan stream (population A), Ligeiro stream (population B), Sarandi river (population C) and Água do Rancho river (population D) indicated the existence of inter- and intrapopulation variations in the number of NORs. The present study also showed a probable mechanism of preferential activation of nucleolar chromosomes, suggesting the presence of main activators as well as different activation patterns in each population. In population A, the large metacentric chromosome was the main nucleolar organizer occurring in about $67 \%$ of the cells analyzed, with this population showing the most characteristic NOR pattern compared to the other populations. In populations $\mathrm{B}, \mathrm{C}$ and $\mathrm{D}$, the main nucleolar organizer chromosomes were a large acrocentric chromosome $(65 \%)$, a large submetacentric $(70 \%)$ and a medium-sized submetacentric $(71 \%)$, respectively.
\end{abstract}

Key words NOR-band, Main nucleolar organizer, Activation of NOR, Astyanax scabripinnis, Characidae.

Most studies on the nucleolar organizer region (NOR) use silver staining for the identification of this region. This differential staining, initially described by Howell et al. (1975), has been attributed to its affinity for acidic proteins that are specifically associated with these regions. There is evidence that this technique stains only the NORs which have been active at the previous interphase (Howell et al. 1975, Goodpasture and Bloom 1975).

Other techniques identifying the nucleolar organizer region are those using GC-specific fluorochromes such as mitramycin and chromomycin $\mathrm{A}_{3}$, since an association between this region and GC-rich segments has been observed in lower vertebrates. This method has been widely used for the detection of possible inactive ribosomal sites, since these fluorochromes stain the NORs regardless of their genetic activity (Gold et al. 1990).

Studies on the nucleolar organizer region in fishes have revealed that most of the species analyzed have only one pair of NORs (Curimatidae, Anostomidae, Parodontidae, Prochilodontidae, Cichlidae). However, species with multiple NORs have been described for various groups, among them Characidae, Lebiasinidae, Loriicaridae, Erythrinidae and Callichthydae.

Variations in the NOR system have been found within different subfamilies of the family Characidae, including those with only one NOR-bearing chromosome (Cheirondontinae, Salmininae and Bryconinae) and those with various NOR chromosomes (Acestrohynchinae, Cynopotaminae, Serrasalminae, Tetragonopterinae and Triportheinae). In addition, both intra- and interspecies polymorphisms in the size and number of the NORs have been observed.

Studies on species with multiple NORs indicated the presence of a main pair of nucleolar organizers which was always found to be stained with silver. Bertollo and Cavallaro (1992), studying Triporteus guentheri, reported a NOR system encompassing two autosomes and the Z sex chromosome, with chromosome 9 being the main nucleolar organizer. This observation suggested the existence of a mechanism which preferentially activates these chromosomes in multiple NOR systems.

Therefore, the objective of the present study was to analyze the nucleolar organizer region in 
different $A$. scabripinnis populations in order to detect the presence of main nucleolar organizer and possible patterns of preferential activation of ribosomal genes.

\section{Materials and methods}

Four A. scabripinnis populations belonging to three different hydrographic basins were studied. Population A was collected from the Yukatan stream and population B from the Ligeiro stream, both belonging to the Ivai basin, population $\mathrm{C}$ was collected from the Sarandi stream, belonging to the Paranapanema basin, and population D was collected from the Água do Rancho stream, belonging to the Paraná basin. Mitotic metaphases were obtained according to the air drying technique described by Bertollo et al. (1978) and submitted to silver staining, according to the method of Howell and Black (1980).

To determine the existence of preferential activation of the rDNA genes located on one given chromosome in each population, the number of active NORs and the chromosome type containing this region were determined in each metaphase cell. The percentage of activation for each of the different nucleolar chromosome types and the most frequent activation patterns were determined for each populations.

\section{Results}

Differential silver staining of the nucleolar organizer region revealed the existence of multiple NORs in the 4 A scabripinnis populations, with all populations presenting the peculiarity that only one of the homologous chromosomes was silver-stained. Table 1 shows the frequency of the number of NORs in each population. In population A, the NORs were located on one metacentric, one submetacentric and one acrocentric chromosome, in population B on two submetacentric and two acrocentric chromosomes, in population $\mathrm{C}$ on one metacentric, three submetacentric and two acrocentric chromosomes, and in population $\mathrm{D}$ on three submetacentric and two acrocentric chromosomes (Fig. 1). Although population C presented a maximum number of 5 NORs per cell, the number of NOR-bearing chromosomes was 6 (Fig. 1).

To determine the existence of preferential activation of chromosomes within the multiple NOR system, the number of NORs and the type of chromosome involved were determined in 90 metaphases for population A, 93 for B, 143 for C and 115 for D (Table 1). The frequency of each type of active chromosome in each population is shown in Tables 2-5.

Based on the frequency values of the active NOR patterns, it was possible to determine the most frequent activation patterns in each population (Fig. 2).

\section{Discussion}

Most studies on the nucleolar organizer region of $A$. scabripinnis populations reported the oc-

Table 1. Frequence of number of NOR in each Astyanax scabripinnis populations

\begin{tabular}{|c|c|c|c|c|c|c|c|}
\hline \multirow{2}{*}{ Population } & \multirow{2}{*}{ Bacin. } & \multicolumn{5}{|c|}{ Number of NORs } & \multirow{2}{*}{ Total } \\
\hline & & 1 & 2 & 3 & 4 & 5 & \\
\hline A & Ivaí & 51 & 21 & 18 & - & 一 & 90 \\
\hline $\mathrm{B}$ & Ivaí & 47 & 34 & 10 & 2 & - & 93 \\
\hline $\mathrm{C}$ & Pirapó & 9 & 57 & 62 & 13 & 2 & 143 \\
\hline $\mathrm{D}$ & Paraná & 20 & 35 & 47 & 11 & 2 & 115 \\
\hline
\end{tabular}




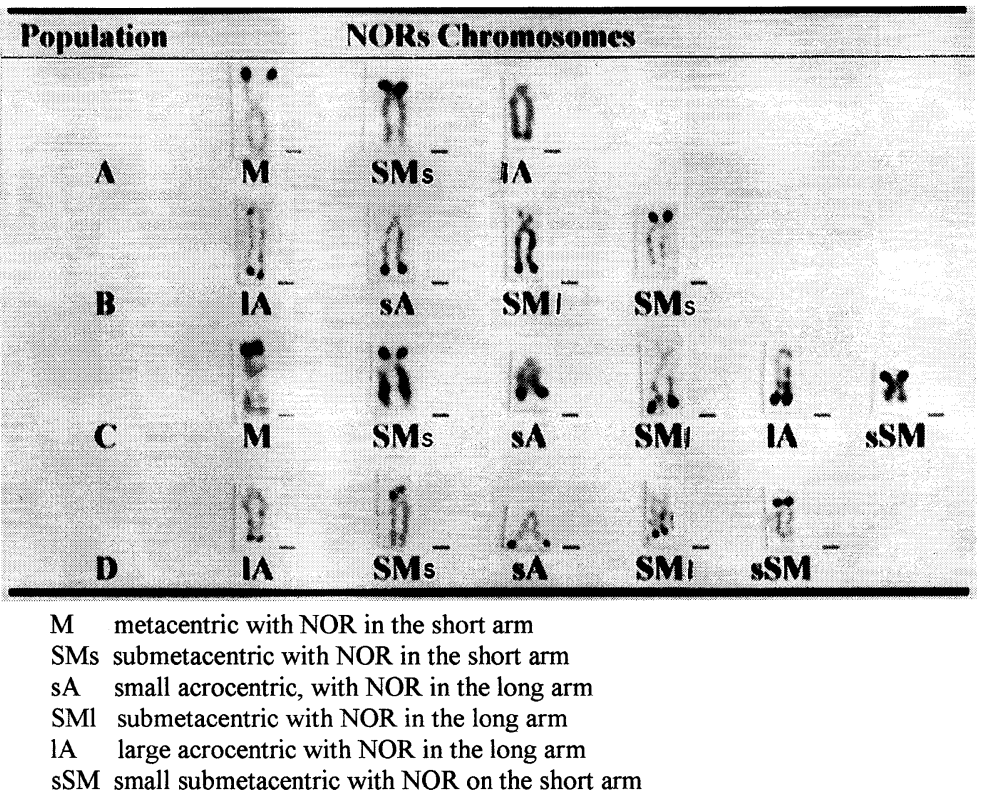

Fig. 1. Number and type of NOR-bearing chromosome for each of the Astyanax scabripinnis populations.

Table 2. Frequence of activation for each of the different nucleolar chromosome types in the population A of Astyanax scabripinnis

\begin{tabular}{|c|c|c|c|c|}
\hline \multirow{2}{*}{ Specimens } & \multicolumn{3}{|c|}{ Chromosome types with active NORs } & \multirow{2}{*}{ Total } \\
\hline & M & SMs & $1 \mathrm{~A}$ & \\
\hline $12 \mathrm{~A}$ & 4 & 3 & 2 & 9 \\
\hline $8 \mathrm{~A}$ & 21 & 17 & 11 & 49 \\
\hline $77 \mathrm{~A}$ & 13 & 13 & 7 & 33 \\
\hline $75 \mathrm{~A}$ & 3 & 3 & 2 & 8 \\
\hline $20 \mathrm{~A}$ & 8 & 6 & 4 & 18 \\
\hline $18 \mathrm{~A}$ & 11 & 11 & 6 & 28 \\
\hline Total & 60 & 53 & 32 & 145 \\
\hline$\%$ & 41.4 & 36.5 & 22.1 & 100 \\
\hline
\end{tabular}

M: metacentric with NOR in the short arm. SMs: submetacentric with NOR in the short arm. 1A: acrocentric with NOR in the long arm.

currence of active NOR in only one homologous of the chromosome pair (Moreira-Filho 1989, Maistro 1991, Souza 1996). In the present study this aspect was caracteristic, however, population A had 3 chromosomes containing ribosomal genes, suggesting that 3 chromosome pairs are involved with this region. Populations B, C and D even presented 4, 6 and 5 nucleolar chromosomes, respectively. Therefore, the populations differed both in the number and type of chromosome containing the nucleolar organizer region (Fig. 1).

The analysis of the nucleolar organizer regions of $A$. scabripinnis has revealed both intra- and interpopulation variations (Moreira-Filho 1989, Maistro 1991, Souza 1996). Cells with only one pair of nucleolar organizer chromosomes were observed in an individual $(2 n=48)$ belonging to population Tamanduá river $(2 \mathrm{n}=50$, Maistro 1991), and in the 3 populations studied by Vicente 
Table 3. Frequence of activation for each of the different nucleolar chromosome types in the population $\mathrm{B}$ of Astyanax scabripinnis

\begin{tabular}{|c|c|c|c|c|c|}
\hline \multirow{2}{*}{ Specimens } & \multicolumn{4}{|c|}{ Chromosome types with active NORs } & \multirow{2}{*}{ Total } \\
\hline & $1 \mathrm{~A}$ & sA & SMl & SMs & \\
\hline $11 \mathrm{~B}$ & 25 & 13 & 14 & 7 & 59 \\
\hline 07B & 13 & 7 & 1 & 5 & 20 \\
\hline 09B & 5 & 6 & 6 & 2 & 19 \\
\hline $10 \mathrm{~B}$ & 13 & 9 & 9 & 6 & 37 \\
\hline 08B & 4 & 1 & 2 & 2 & 9 \\
\hline Total & 60 & 36 & 31 & 17 & 144 \\
\hline$\%$ & 41.7 & 25.0 & 21.5 & 11.8 & 100 \\
\hline
\end{tabular}

1A: large acrocentric with NOR in the long arm. sA: small acrocentric with NOR in the long arm. SMl: submetacentric with NOR in the long arm. SMs: submetacentric with NOR in the short arm.

Table 4. Frequence of activation for each of the different nucleolar chromosome types in the population $\mathrm{C}$ of Astyanax scabripinnis

\begin{tabular}{|c|c|c|c|c|c|c|c|}
\hline \multirow{2}{*}{ Specimens } & \multicolumn{6}{|c|}{ Chromosome types with active NORs } & \multirow{2}{*}{ Total } \\
\hline & M & SMs & sA & SMI & $1 \mathrm{~A}$ & sSM & \\
\hline $21 \mathrm{C}$ & - & 4 & 4 & - & 1 & - & 9 \\
\hline $18 \mathrm{C}$ & 6 & 27 & 21 & 16 & 6 & 13 & 89 \\
\hline $08 \mathrm{C}$ & - & 3 & 1 & 1 & 1 & 1 & 7 \\
\hline $15 \mathrm{C}$ & 2 & 2 & - & 1 & 2 & 2 & 9 \\
\hline $11 \mathrm{C}$ & 1 & 1 & 1 & 2 & 1 & 1 & 7 \\
\hline $22 \mathrm{C}$ & 9 & 14 & 6 & 10 & 9 & 4 & 52 \\
\hline $33 \mathrm{C}$ & - & 4 & - & 1 & 5 & 1 & 11 \\
\hline $79 \mathrm{C}$ & - & 4 & 3 & 1 & 4 & 2 & 14 \\
\hline $47 \mathrm{C}$ & 3 & 5 & 6 & 6 & 7 & 6 & 33 \\
\hline $10 \mathrm{C}$ & 1 & 4 & 12 & - & 1 & 1 & 9 \\
\hline $20 \mathrm{C}$ & 3 & 13 & 10 & 16 & 7 & 5 & 54 \\
\hline $14 \mathrm{C}$ & 2 & 12 & 14 & 12 & 8 & 5 & 53 \\
\hline $19 \mathrm{C}$ & 1 & 7 & 3 & 7 & 3 & 4 & 25 \\
\hline Total & 28 & 100 & 71 & 73 & 55 & 45 & 372 \\
\hline$\%$ & 7.5 & 26.9 & 19.1 & 19.6 & 14.8 & 12.1 & 100 \\
\hline
\end{tabular}

M: metacentric with NOR in the short arm. SMs: submetacentric with NOR in the short arm. sA: small acrocentric, with NOR in the long arm. SMl: submetacentric with NOR in the long arm. 1A: large acrocentric with NOR in the long arm. sSM: small submetacentric with NOR on the short arm.

(1994). However, population (Rio Jucu) were found with up to 15 NOR-bearing chromosomes, suggesting that 13 chromosome pairs are involved (Rocon-Stange and Almeida-Toledo 1993). Therefore, extensive variations occur in the NOR system of $A$. scabripinnis.

Furthermore, the analyses of the NOR patterns summarized in Tables 2-5 indicate differences in the activation pattern of the chromosomes between populations during interphase. Although the ribosomal genes of these Astyanax scabripinnis populations do not present a strict activation pattern, the present results suggest that a mechanism may exist which preferentially activates rDNA genes located on given chromosomes.

Regarding the frequency at which different NOR-stained chromosomes occur, population A 
Table 5. Frequence of activation for each of the different nucleolar chromosome types in the population D of Astyanax scabripinnis

\begin{tabular}{|c|c|c|c|c|c|c|}
\hline \multirow{2}{*}{ Specimens } & \multicolumn{5}{|c|}{ Chromosome types with active NORs } & \multirow{2}{*}{ Total } \\
\hline & $1 \mathrm{~A}$ & SMs & sA & SM1 & sSM & \\
\hline $52 \mathrm{D}$ & 29 & 19 & 18 & 33 & 9 & 108 \\
\hline $21 \mathrm{D}$ & 7 & 10 & 9 & 12 & 5 & 43 \\
\hline $48 \mathrm{D}$ & 16 & 32 & 15 & 27 & 12 & 102 \\
\hline $40 \mathrm{D}$ & 9 & 2 & 6 & 9 & 1 & 27 \\
\hline Total & 61 & 63 & 48 & 81 & 27 & 280 \\
\hline$\%$ & 21.8 & 22.5 & 17.2 & 28.9 & 9.6 & 100 \\
\hline
\end{tabular}

1A: large acrocentric with NOR in the long arm. SMs: large submetacentric with NOR in the short arm. Ap: small acrocentric, with NOR in the long arm. SMl: median submetacentric with NOR in the long arm. sSM: small submetacentric with NOR in the short arm.

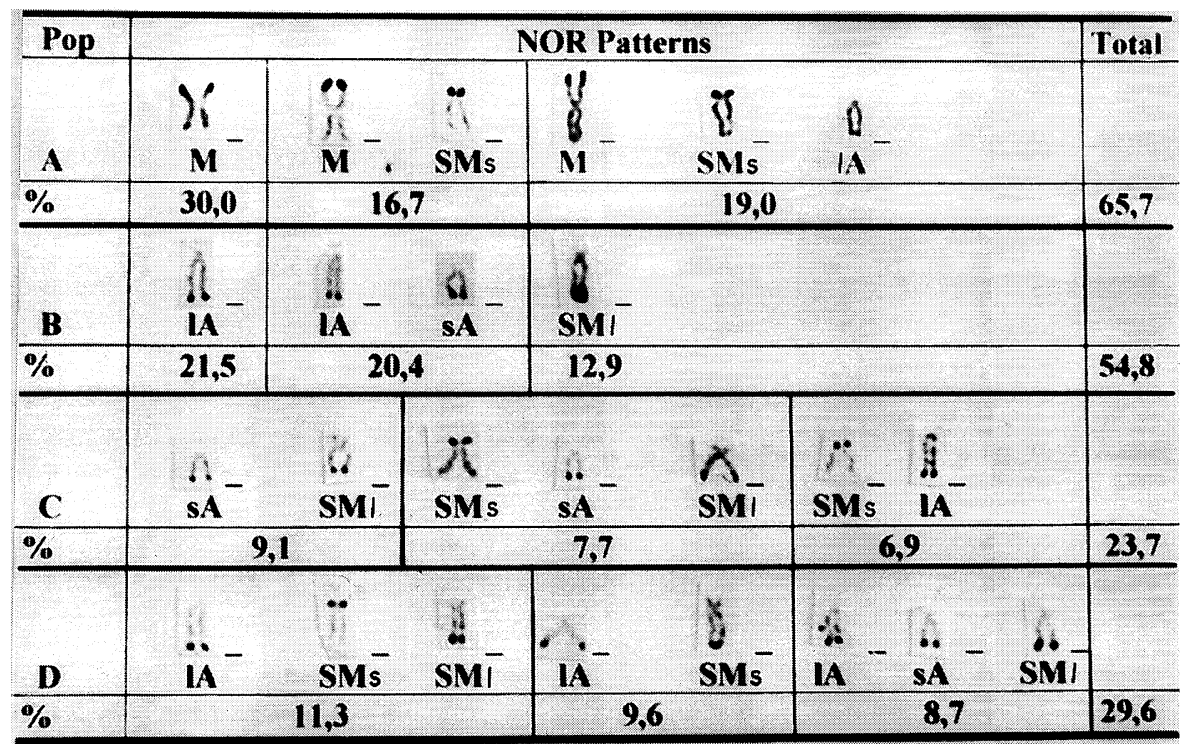

M metacentric with NOR in the short arm

SMs submetacentric with NOR in the short arm

sA small acrocentric, with NOR in the long arm

SMl submetacentric with NOR in the long arm

1A large acrocentric with NOR in the long arm

sSM small submetacentric with NOR on the short arm

Fig. 2. Activation patterns most frequent for each of the Astyanax scabripinnis populations.

showed a more typical activation pattern than the other populations, with cells having only one stained chromosome being the most ffequent ones (Table 1). In this case, the active chromosome was a medium-sized metacentric (Fig. 2). This chromosome was also present in other combinations of two or three active NORs, indicating that it is the main nucleolar organizer occurring in about $67 \%$ of the 90 cells analyzed (Tables 1,2 ).

For population $\mathrm{B}$, the most frequent pattern observed was that whose cells presented only one active stained chromosome (Table 1), with cells containing NORs located on the long arm of a large acrocentric chromosome being the most frequent ones (Fig. 2). This chromosome was also found 
together with other nucleolar chromosomes showing patterns of two, three and up to four chromosomes (Table 1). Nevertheless cells with NOR in one chromosome of the type large acrocentric or submetacentric or in two chromosomes being one large acrocentric and one small acrocentric, formed the three patterns of NOR most frequents of this population (Fig. 2). This indicates that this large acrocentric chromosome is the main nucleolar chromosome occurring in about $65 \%$ of the 93 cells analyzed (Tables 1,3). On the other hand, populations $\mathrm{C}$ and $\mathrm{D}$ which had a large number of NOR-bearing chromosomes did not show a specific activation pattern, nevertheless, the present results indicate the existence of main chromosomes involved in rDNA gene activation.

Of the 6 NOR-bearing chromosomes observed in population $\mathrm{C}$, the submetacentric chromosome with terminal staining on the short arm (SMs) was the main activator, occurring in about $70 \%$ of the 143 cells analyzed (Tables 1,4$)$. In addition, the submetacentric chromosomes with terminal staining on the long arm (SMl) and the small acrocentric chromosome stained on the long arm (sA) were also highly frequent, occurring in $51 \%$ and $50 \%$ of the cells, respectively, which, taken together with the main activator, formed the three most frequent NOR activation patterns of this population (Fig. 2).

In population $\mathrm{D}$, the main activator was the submetacentric chromosome with terminal stained on the long arm (SMl), which was observed in $70 \%$ of the 115 cells analyzed (Tables 1,5 ), however, the acrocentric chromosome (Al) with terminal staining on the long arm and the submetacentric chromosome with terminal staining on the short arm (SMs) showed a frequency of $55 \%$ and $54 \%$, respectively, which, taken together with the main activator, formed the three most frequent patterns of this population (Fig. 2).

In summary, the activation of NORs in A. scabripinnis seems to involve a mechanism of gene regulation which permits the preferential expression of genes of a given main nucleolar chromosome in multiple NOR system.

\section{Acknowledgments}

The authors are grateful to CNPq for financial support.

\section{References}

Bertollo, L. A. C. and Cavallaro, Z. I. 1992. A highly differentiated ZZ/ZW sex chromosome system in a Characidae fish Triportheus guentheri. Cytogenetic. Cell Genet. 60: 60-63.

-, Takahashi, C. S. and Moreira-Filho, O. 1978. Cytotaxonomic consideration on Hoplias lacerda (Pisces, Erythrinidae). Rev. Bras. Genética 1(2): 103-120.

Gold, J. R., Li, Y. C., Shipley, N. S. and Powers, P. K. 1990. Improved methods for working with fish chromosomes with a review of metaphase chromosome banding. J. Fish Biology 37: 563-575.

Goodpasture, C. and Bloom, S. E. 1975. Visualization of Nucleolar Organizer Regions in mammalian chromosomes usingsilver staining. Chromosoma (Berl.) 53: 37-50.

Howell, W. M. and Black, D. A. 1980. Controlled silver-staining of nucleolus organizer regions with a protective colloidal developer: a I-step method. Experientia 36: 1014-1015.

-, Denton, T. E. and Diamont, J. R. 1975. Differential staining of the satellite regions of human acrocentric chromosomes. Experientia 31: 260-262.

Maistro, E. L. 1991. Caracterização citogenética e morfológica de populações de Astyanax scabripinnis paranae (Pisces, Characidae) das bacias dos rios Tietê e Paranapanema. Dissertação de mestrado. Departamento de Genética do Instituto de Biociências, Universidade Estadual Paulista, Botucatu, São Paulo.

Moreira-Filho, O. 1989. Análise cariotípica e morfológicas sobre a diversidade no "complexo" scabripinnis (Jennis, 1842) (Pisces, Characidae, Tetragonopterinae). Tese de doutorado. Departamento de Ciências Biológicas, Universidade Federal de São Carlos.

Rocon-Stange, E. A. and Almeida-Toledo, L. F. 1993. Supernumerary B chromosomes restricted to males in Astyanax scabripinnis (Pisces, Characidae). Rev. Bras. de Genética 16(3): 601-615.

Souza, I. L. 1996. Estudos citogenéticos em populações de Astyanax scabripinnis (Pisces, Characidae) pertencentes a dois 
riachos de diferentes bacias do Sudeste Brasileiro. Dissertação de mestrado. Programa de Pós-graduação em Genética e Evolução, Universidade Federal de São Carlo. São Carlos, S. P.

Vicente, V. E. 1994. Estudos do cromossomos B em três populações de Astyanax scabripinnis (Pisces, Characidae). Dissertação de mestrado. Departamento de Ciências Biológicas. Universidade Federal de São Carlos. S. P. 